Journal of The Faculty of Science and Technology (JFST)

http://journal.oiu.edu.sd/index.php/JFST

https://doi.org/10.52981/jifst.vi7.959

ISSN: 1858 - 6007

مجلة العلوم و التقانة - جامعة أم درمان الإسلامية - وزارة التعليم العالي و البحث العلمي ـ السودان

Research article

JFST Issue No. 7 (2020) 85 - 92

\title{
Fungal Contamination of Some Medicinal Plant Materials Sold at Omdurman Local Market, Khartoum State, Central Sudan
}

Ehsan Musa Ewad EL-Kareem*1 ${ }^{1}$, Hatil Hashim EL-Kamali ${ }^{1}$, Ahlam Salih Eltahir ${ }^{1}$ and Hanan Ibrahim Mudawi ${ }^{4}$

${ }^{1}$ Botany Department, Faculty of Science and Technology, Omdurman Islamic University, Omdurman, Sudan

${ }^{2}$ Environment and Natural Resources Research Institute . National Centre for Research, Khartoum, Sudan

\section{Abstract}

Plants have long been used as herbal medicines in many countries. However, microbial contamination of these medicines may affect human health. In the present study fifteen medicinal plants namely, Acacia nilotica ssp. nilotica, Trigonella foenum-greacum, Nigella sativa, Hyphaene thebaica, Nauclea latifola, Cyperus rotundus, Cymbopogon schoenanthus spp, proximus, Artemisia herba-alb, Cassia acutifolia, Solenostemma argel, Tamarindus indica, Ziziphus spina-christi, Lepidium sativum, Foeniculum vulgare and Coriandrum sativum were evaluated for their fungal contamination. The pour plate method was used to cultivate serially diluted portions of the medicinal plant material investigated. The colonies of fungi were identified morphologically according to form and pigment. They were observed microscopically through Lactophenol cotton bluestaining. The identified fungal isolates were consist of three fungal species, the most dominant fungi were Aspergillus nigar and Aspergillus flavus. Penicillium ssp is least one. The total fungal counts ranged from 00x $10^{1} \mathrm{cfu} / \mathrm{g}$ (Cymbopogon schoenanthus spp.proximus, Trigonella foenum-greacum, Artemisia herba alb, Lepidium satinum, Nigella sativa Cassia acutifolia and Naucle latifola) to $11 \times 10^{5} \mathrm{cfu} / \mathrm{g}$ (Cyperus rotundus).. The highest total fungal load was found in Cyperus rotundus The levels of contamination varied greatly between the commercially available plant samples investigated. 


\section{Key words:}

Fungal, Contamination, Aspergillus nigar, Aspergillus flavus Penicillium ssp

\section{Introduction}

Microbial contamination of medicinal herbal can be influenced by environmental factor such a temperature, humidity and extent of rainfall during pre-harvesting and post-harvesting periods, handling practices and the storage condition of cured and processed medicinal-plant materials. The presence of lipolytic mould such as Penicillium ssp. and Aspergillus nigar have been implicated in food poisoning (Bampton, 1963). Although bacterial endospores and fungal spores can be regarded as the two dominating groups of contaminants associated with medicinal plants, a broad diversity of bacterial, fungal cells and viruses can be found either in or on the plant material (Kneifel and Kopp, 2002)..

It is known that, under favorable conditions, some fungi can synthesize toxic metabolites mycotoxins. Among the known mycotoxins, the most toxic one is alfatoxin synthesized by species of $A$. flavus and A. parasiticus, and a minor number of other fungi (Kulshrestha et $a l$, 2008). Contamination by A. flavus, the most famous aflatoxin producer, is common in medicinal plants and herbal tea (Halt, 1998). In study of 91 medicinal herb samples in Brazil Bugno et al (2005) found that 50\% of aerial part samples were contaminated with fungi. Moulds are responsible for bio-deterioration of raw materials of some medicinal plants .These moulds reduce raw herbal drug shelf life and market value. The fungal deterioration adversely affects the chemical composition of the raw materials and therapy decreases the medicinal potency of herbal drug Kumar et al, (2009). There is a need for consistent quality assessment of crude herbal drugs for safe therapeutic products suitable for human beings (Chanda et al. 2019). The present study aimed to throw light on the fungal load of some medicinal plants of widely uses in Sudan.

\section{Materials and Methods}

\section{Plant Materials}

A total number of fifteen different medicinal plant parts (Table 1) were purchased from a local market in Omdurman, Khartoum State, central Sudan (during the period SeptemberOctober, 2016). The Plant parts were collected aseptically with gloves in to sterile pouches. 
The plants were identified at the Botany Department, Faculty of Science and Technology, Omdurman Islamic University.

\section{The Media}

Malt extract agar and Potato dextrose agar were used to enumerate the total fungi population.

\section{Sample Preparation:}

The dried plant samples were cleaned to remove adhering polyethylene and other unwanted materials. The samples were stored at $4^{\circ} \mathrm{C}$ till further analysis

\section{Procedure for Determination:}

The determination of fungi contamination was established for fungal load, total fungi count and specific pathogen in the studied medicinal plant samples. For calculation of fungal contents, the plant materials were tested to determine the number of microorganisms per gram samples. The standard plate count method was used for detecting and determining the number of microorganism in plant materials. One gram of each of the studied plant parts were infused in $9 \mathrm{ml}$ of distilled water. Serial dilutions were made; viability assessed using Pour Plate method. The plates were incubated at $25^{\circ} \mathrm{C}$ for 10 days. The plates were placed on a colony counter and the number of Colony Forming Units was taken. Then all isolates were identified by using colonies morphological characters: form and pigment (Cheesbrough, 1984). 


\section{Table 1: The studied plants}

\begin{tabular}{|c|c|c|c|c|}
\hline No & Plant Species & Plant Part & Family & Medicinal Uses \\
\hline 1 & Acacia nilotcia ssp.nilotica & Pods & Fabaceae & $\begin{array}{l}\text { anti-hyperglycemic, } \\
\text { antiplasmodial, anti inflammatory, } \\
\text { analgesic and antipyretic }\end{array}$ \\
\hline 2 & Artemisia herba alb & Aerial Parts & Asteraceae & $\begin{array}{l}\text { diuretic, anthelmintic, intestinal } \\
\text { troubles, relieves gastro-intestinal } \\
\text { cramps }\end{array}$ \\
\hline 3 & Cassia acutifolia & Friuts & Fabaceae & $\begin{array}{l}\text { flavoring agent and a traditional } \\
\text { medicinal herb }\end{array}$ \\
\hline 4 & Coriandrum sativum & Fruits & Apiaceae & $\begin{array}{l}\text { diabetes, an anti-fungal, } \\
\text { hypolipidemic, antimicrobial, } \\
\text { hypo cholesterolemic and } \\
\text { anticonvulsant }\end{array}$ \\
\hline 5 & $\begin{array}{l}\text { Cymbopogonschoenanthus spp, } \\
\text { proximus }\end{array}$ & Aerial Parts & Poaceae & $\begin{array}{l}\text { treat fever, cold, cough, stomach } \\
\text { upset, diuretic, and water retention }\end{array}$ \\
\hline 6 & Cyperus rotundus & Roots & Cypraceae & $\begin{array}{l}\text { spasms, stomach disorder and } \\
\text { inflammatory diseases. }\end{array}$ \\
\hline 7 & Foeniculum velgare & Fruits & Apiaceae & Diuretic, analgesic and antipyretic \\
\hline 8 & Hyphaene thebaica & Fruits & Palmae & $\begin{array}{l}\text { bilharziasis, haematuria, Bleeding } \\
\text {, and as haematinic agent }\end{array}$ \\
\hline 9 & Lepidium sativum & Seeds & Brassicaceae & $\begin{array}{l}\text { in asthma, coughs and bleeding } \\
\text { piles. }\end{array}$ \\
\hline 10 & Nauclea latifola & Fruits & Naucleae & $\begin{array}{l}\text { stomach pain, constipation, fever, } \\
\text { and diarrhea }\end{array}$ \\
\hline 11 & Nigella sativa & Seeds & Ranunculaceae & $\begin{array}{l}\text { headache, nasal congestion, } \\
\text { toothache, intestinal worms and } \\
\text { diuretic }\end{array}$ \\
\hline 12 & Solenostemma argel & Leaves & Apocynaceae & $\begin{array}{l}\text { stomach colic, cold, urinary tract } \\
\text { infections and as an anti-syphilitic }\end{array}$ \\
\hline
\end{tabular}




\begin{tabular}{|c|c|c|c|c|}
\hline 13 & Tamarindus indica & Fruits & Fabaceae & $\begin{array}{l}\text { cold, fever, stomach disorder, } \\
\text { diarrhea and jaundice and as skin } \\
\text { cleanser }\end{array}$ \\
\hline 14 & Trigonellafoenum-greacum & Seeds & Fabaceae & $\begin{array}{l}\text { aiding digestion,. Hypoglycemic, } \\
\text { anti hyperlipidemic }\end{array}$ \\
\hline 15 & Ziziphus spina-christi & Fruits & Rhamnaceae & $\begin{array}{l}\text { healing of fresh wounds, for } \\
\text { dysentery, bronchitis, cought and } \\
\text { tuberculosis }\end{array}$ \\
\hline
\end{tabular}

\section{Results :}

A total number of three fungal strains were isolated from the fifteen studied medicinal plant parts, then they were investigated and identified. They were Aspergillus niger, Aspergillus flavus and Penicillium spp. From the fifteen investigated plants eight plants were found to be contaminated and seven plants not contaminated. Table 2 shows the distribution of the fungal load from the studied plant parts. The dominant fungi in most of the tested samples belong to Aspergillus niger. where as the least one was Penicillium spp. Morphologically, the colonies of fungi were identified according to form and pigment. They were observed microscopically through Lactophenol cotton bluestaining. Plate (1) shows the results of culture characteristic .

Table 2: Total fungal Count of Selected Medicinal Plant materials obtained From Omdurman Local Market/Sudan

\begin{tabular}{|l|l|l|}
\hline Plant species & Count of fungi & Predominant fungal species isolated \\
\hline Acacia nilotica ssp.nilotica & $1 \times 10^{1}$ & Penicillium spp \\
\hline Artemisia herba alba & $\mathrm{NIL}$ & No growth \\
\hline Cassia acutifolia & $\mathrm{NIL}$ & No growth \\
\hline Coriandrum satinum & $5 \times 10^{2}$ & Aspergillus nigar. \\
\hline $\begin{array}{l}\text { Cymbopogon schoenanthus } \\
\text { spp.proximus }\end{array}$ & $\mathrm{NIL}$ & No growth \\
\hline Cyperus rotundus & $11 \times 10^{5}$ & Aspergillus nigar \\
\hline Foeniculum velgare & $6 \times 10^{2}$ & Aspergillus nigarand Aspergillus flavus \\
\hline Hyphaene thebaica & $9 \times 10^{3}$ & Aspergillus nigar \\
\hline Lepidium sativum & $\mathrm{NIL}$ & No growth \\
\hline
\end{tabular}




\begin{tabular}{|l|l|l|}
\hline Naucla latifola & NIL & No growth \\
\hline Nigella sativa L. & NIL & No growth \\
\hline Solenostemma argel & $3 \times 10^{2}$ & Aspergillus nigar. \\
\hline Tamarindus indica & $4 \times 10^{1}$ & $\begin{array}{l}\text { Aspergillus nigar, Aspergillus flavus and } \\
\text { Penicillium spp }\end{array}$ \\
\hline Trigonella foenum-greacum & NIL & No growth \\
\hline Ziziphus spina-christi & $3 \times 10^{1}$ & Aspergillus nigar. \\
\hline & & \\
\hline
\end{tabular}

Plate (1): Morphological Appearance of the fungal colonies a. Aspergillus niger, b. A. flavus, c. Penicillium spp.

\section{Discussion:}

The present study revealed that commercially available medicinal herbs might be high-risk materials, as it contained pathogenic fungal load. Among the studied plants, seven plants are not contaminated and may be because they are dry, all the three seeds investigated are free of fungal contamination, six of eight fruits are contaminated because the fruits are delicate and so acceptable to infection. A. niger was recorded as most abundant whereas Penicillium spp was found to the least abundant fungal specie. Aspergillus species has the potential for toxin production in the products. Raw materials of good microbial quality should be used in the production of these medicinal herbs.

Another investigation reported that Aspergillus spp. was recorded as one of most abundant fungi in the samples of prepared powdered herbal medicine while, the herbs were collected from certain areas of Nigeria. (Anyanwu, 2010).. Medicinal plants can be dried in a number of ways: in the open air (shaded from direct sunlight) by direct sunlight, in rooms, in the case of achieve uniform drying of medicinal plant materials to avoid mould formation(WHO, 2003). To prevent from these contaminants special hygienic, care must be taken like soak during boiling of water and kept in air tight tumbler Ara et al, (2015). Rizzo et al. (2004) indicated that medicinal plants in Argentina harbored toxigenic fungi such as A. flavus, A. 
parasiticus and several members of the Genus Fusarium. The incidence of toxigenic fungi producing aflatoxins, ochratoxin $\mathrm{A}$ and fumonisin on medicinal herbs was reported from Argentina . Aflatoxins, ochratoxin A and citrinin producing Aspergillus and Penicillium were isolated from medicinal herbs in Brazil Bugno, et al (2006).

\section{Conclusion:}

The results of this study revealed that the use of these herbs as home remedy could be prolong the infections and ultimately cause other disease since it was observed that herbal remedies were not sterile and herbs are available in market in open air, so aerial contamination risk is very high. The delicate and soft organs like fruits and leaves are more acceptable to fungal contamination than the hard seeds and roots.

\section{Acknowledgments:}

Thanks to Dr Mutaz Nassir for help and to microbiology commission for Biotechnology and Genetic Engineering Khartoum.

\section{References:}

Anyanwu, C. U. (2010). Fungal contaminants of powdered herbal drugs sold in parts of Enugu State, Southeast, Nigeria. Plant Product Research Journal, 14, 46-50.

Ara Darakhshani, Anwer Humera and Parween Rubina, (2015), Microbial Contamination In Herbs Fuuast J. Biol., 5(2): 197-199

Bampton S S (1963). Fusarium oxysporum toxicosis in ducks. Veterianiya, 43:54-55. Bugno, A., Buzzo,A.A., Nakamura,C.T., Pereira,T.C., Matos,D., and Pinto,T.J.A.(2005). Avaliacao da contaminacao microbiana em drogas vegetais. Revista Brasileira de ciencias farmacceuticas,41(4),491-497.

Bugno, A., Almodovar, A.A.B., Pereira,T.C, Pinto,T.J.A. and Sabino,M. (2006). Occurrences of toxigenic fungi in herbal drug.

Chandra, H., Kumari, P. \& Yadav, S. Evaluation of aflatoxin contamination in crude medicinal plants used for the preparation of herbal medicine. Orient Pharm Exp Med 19, 137-143 (2019). https://doi.org/10.1007/s13596-018-0356-4 
Cheesbrough, M.(1984). Culture Media. In: Medical Laboratory Manual for Tropical Countries. Tropical Health Technology and Butterworth-Heineman. Cambridge.3:60-9,40728.

Halt, M.(1998).Moulds and aMycotoxin in Hetti and Medicinal Plants.Erurepean Journal of Epidemiology,14:269-274

Kneifel ,W,Czech ,E, and Kopp,B.(2002).Microbial contamination of medicinal plants-A review .planta medica ,5-15,.68.

Kulshrestha,R.,Gupta,C.P.,Shukla,G.,Kundu,M.G.,Bhatnagar,S.P.,and Katiyar,C.K .(2008). The effect of water activity and storage temperature on the growth of Aspergillus flavus in medicinal herbal.planta medica,74,1308-1315.

Kumar,A.,Shukla,R.,Singh,P.,and Dubey,N.K.(2009).Biodeterioration of some herbal raw materials by storage fungi and alfatoxin and assessment of Cymbopogon flexuosus essential oil and it components as antifungal. International Biodeterioration and biodegradation ,63,712-716.

Rizzo, I., Vedoya, G. and Maurutto, S. (2004). Assessment of toxigenic fungi on Argentinean medicinal plants. Microbiology Research 159, 113-120.

World Health Organization (WHO).(2003). WHO guidelines on good agricultural and collection practices (GACP) for medicinal plants. Geneva, World Health Organization . 